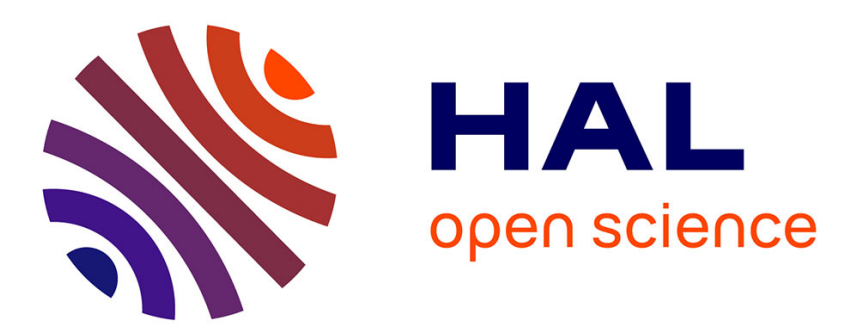

\title{
The Efficiency View of Corporate Boards: Theory and Evidence
}

\author{
Angelo Baglioni, Luca V.A. Colombo
}

\section{To cite this version:}

Angelo Baglioni, Luca V.A. Colombo. The Efficiency View of Corporate Boards: Theory and Evidence. Applied Economics, 2011, 45 (04), pp.497-510. 10.1080/00036846.2011.605764 . hal-00737930

\section{HAL Id: hal-00737930 \\ https://hal.science/hal-00737930}

Submitted on 3 Oct 2012

HAL is a multi-disciplinary open access archive for the deposit and dissemination of scientific research documents, whether they are published or not. The documents may come from teaching and research institutions in France or abroad, or from public or private research centers.
L'archive ouverte pluridisciplinaire HAL, est destinée au dépôt et à la diffusion de documents scientifiques de niveau recherche, publiés ou non, émanant des établissements d'enseignement et de recherche français ou étrangers, des laboratoires publics ou privés. 


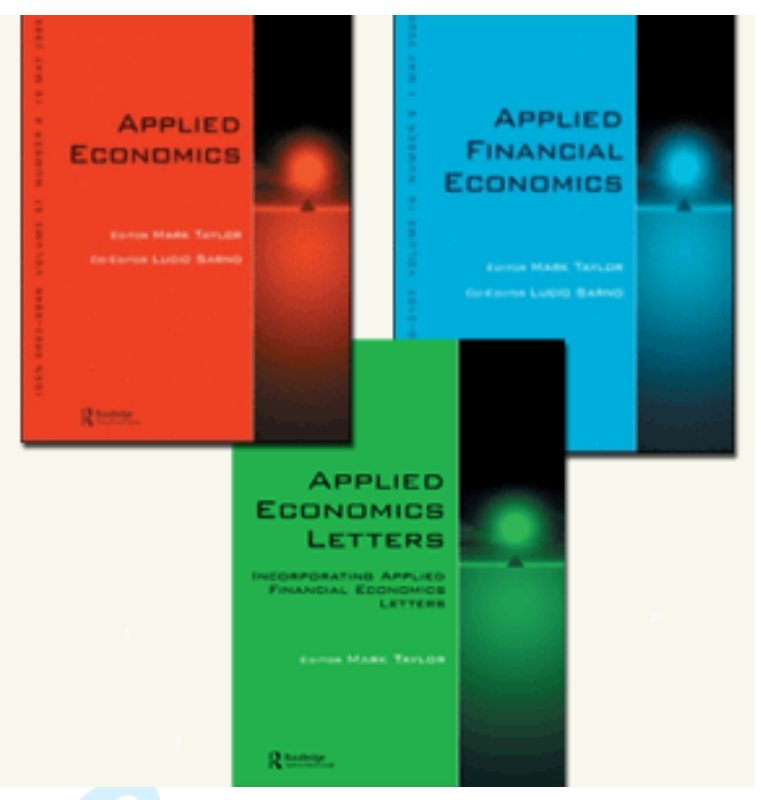

\section{The Efficiency View of Corporate Boards: Theory and Evidence}

\begin{tabular}{|c|c|}
\hline Journal: & Applied Economics \\
\hline Manuscript ID: & APE-2010-0433.R1 \\
\hline Journal Selection: & Applied Economics \\
\hline $\begin{array}{r}\text { Date Submitted by the } \\
\text { Author: }\end{array}$ & 07-Jul-2011 \\
\hline Complete List of Authors: & $\begin{array}{l}\text { Baglioni, Angelo; Catholic University - Milano } \\
\text { Colombo, Luca; Catholic University - Milano }\end{array}$ \\
\hline JEL Code: & $\begin{array}{l}\text { G32 - Financing Policy|Capital and Ownership Structure < G3 - } \\
\text { Corporate Finance and Governance < G - Financial Economics, G34 } \\
\text { - Mergers|Acquisitions|Restructuring|Corporate Governance < G3 - } \\
\text { Corporate Finance and Governance < G - Financial Economics }\end{array}$ \\
\hline Keywords: & $\begin{array}{l}\text { Corporate Boards, Private Benefits, Firm Performance, Agency } \\
\text { Problems }\end{array}$ \\
\hline
\end{tabular}

\section{SCHOLARONE" \\ Manuscripts}




\title{
THE EFFICIENCY VIEW OF CORPORATE BOARDS: THEORY AND EVIDENCE
}

\author{
Angelo Baglioni ${ }^{a}$, Luca Colombo ${ }^{a}$ \\ ${ }^{a}$ Istituto di Economia e Finanza, Università Cattolica, Largo Gemelli 1, 20123 \\ Milano, Italy \\ July 2011
}

\begin{abstract}
We build a model in which corporate governance allows for the adoption of an institution acting as a mechanism to control agency problems. Our model predicts that the incentive to adopt such an institution is decreasing in ownership concentration and increasing in free cash flow. Testing our theoretical model by means of a sample of 157 Italian listed companies over the period 2004-2007, we find that board composition favors independent members in firms with a large free cash flow, and executive members in firms with high ownership concentration, supporting the view of governance as a way to limit agency costs.
\end{abstract}

Keywords: corporate boards, private benefits, firm performance

JEL classification: G32, G34

Acknowledgements. We are grateful to Chiara Donegani for excellent research assistance. We thank the editor and two anonymous referees for their insightful comments that helped improving the paper. We also thank the audiences at the 2009 meeting of the European Economic Association in Barcelona and at the 2010 meeting of the Società Italiana degli Economisti in Catania for valuable comments on a previous version of the paper.

E-mail addresses: angelo.baglioni@unicatt.it, lucava.colombo@unicatt.it 


\section{Introduction}

A growing literature conveys the basic message that corporate boards should be designed to efficiently cope with the separation between ownership and control. However, most contributions refer to environments where firms are public companies, as it is the case in the USA and in UK. In this article, we show that corporate boards are designed to improve efficiency also in countries where firms, even large ones, are characterized by a concentrated ownership, as it is often the case in continental Europe.

Although theoretically convincing, the idea of boards being designed in order to mitigate agency problems can not be taken for granted. It is often heard in policy circles that when firms are closely held, majority shareholders may be tempted to implement corporate governance structures allowing them to effectively direct firms' actions, without properly taking into account the concerns of other stakeholders (such as minority shareholders). This may occur even when it is doubtful that their decisions are consistent with the objective of maximizing firm's value.

The main purpose of this paper is to contrast the efficiency view of corporate boards with that in which corporate governance is organized around the extraction of private rents. To do so, we build a simple model in which a large shareholder can commit to pursue the general interest of shareholders. Despite its simplicity, our model adds to the literature as it allows the trade-off between the efficiency and the rent-extraction views to surface. Furthermore, it delivers testable relationships that can be taken to the data. We apply the predictions of our model to a sample of Italian listed firms. In Italy, closely held firms are the dominant model of corporate governance, so this country is a natural candidate to contrast the two above mentioned views on empirical grounds. Our results can however be of interest for other countries characterized by a high degree of ownership concentration as well.

In our model, a dominant owner - able to extract private benefits of control - may decide to introduce a governance institution in order to avoid the agency costs due to the incentive distortion associated to rent extraction. Such a gover- 
nance institution (e.g., the independent directors and the representatives of small shareholders in the board) works as a commitment device. By adopting it, the dominant owner implicitly commits to let the general interest of all shareholders prevail over her own private benefits. However, the adoption of the institution determines the emergence of interference and coordination costs.

Absent this institution, the equilibrium level of private benefits is negatively related with the degree of ownership concentration, since the incentives of the dominant owner are more aligned with those of the other shareholders when she retains a large stake in the firm. The extraction of private benefits is instead increasing in the level of free cash flow, since the latter can be considered as a proxy for the funds available for discretionary use. Hence, the incentive to adopt a governance institution as a monitor for agency costs is decreasing in ownership concentration and increasing in the firm free cash flow. Obviously, the governance institution should be adopted only when its benefits exceed its costs.

Our theoretical model predicts that the degree of board independence is decreasing in ownership concentration and increasing in the level of free cash flow. Although the expected relationship between board independence and ownership concentration would be the same also under the alternative view of governance as a 'facilitator' of rent extraction by dominant owners, the predicted effect of free cash flow on governance is the opposite. In fact, an owner aiming at maximizing rent extraction would reduce board independence the larger is the scope for private benefits, i.e. the free cash flow.

In order to confront these contrasting views, we empirically investigate the governance of a large sample of listed firms in the Italian stock exchange, over the time interval 2004-2007. Italian firms are indeed very closely held: on average about $57 \%$ of the ownership of all listed firms (the same percentage for those included in our sample) is accounted by the top three shareholders. Furthermore, about $33 \%$ of listed firms (36\% in our sample) are controlled by a single family, and anecdotal evidence maintains that family firms are characterized by a very tight control by their owners, which may sometimes result in a weak representation of the remaining stakeholders.

Our econometric exercises show that board composition favors independent 
members in firms where the free cash flow is large. This finding supports the view of corporate governance as a tool to control agency costs, rather than as a way to maximize rent extraction. Consistently with our theoretical model, we also find that executive members are the majority in the boards of firms with high ownership concentration and of family firms, where small shareholders are more protected by an 'incentive alignment effect'.

In a theoretical perspective, our paper is related to a number of recent contributions to the theory of corporate boards, highlighting the advisory and monitoring roles of directors and claiming that the optimal structure of the board emerges by balancing the costs and benefits of these two tasks (see, e.g., Adams and Ferreira, 2007; Harris and Raviv, 2008). We add to this literature by highlighting the trade-off between the efficiency view and the rent-extraction view of corporate boards.

The results of our empirical analysis are consistent with a number of recent empirical studies, supporting the view that firms design their governance institutions in a way that allows them to minimize the agency costs arising from the separation between ownership and control. Cross-sectional evidence shows that the structure of boards - especially the degree of board independence - depend on firms' features affecting their specific contracting environment, such as their size, ownership concentration, insider ownership, sector of activity, and firm specific knowledge (see, e.g., Del Brio et Al., 2011; Linck et Al.,2007; Lehn et Al., 2009; Boone et Al., 2007; Coles, Naveen and Naveen, 2008). Most of this literature focuses on public companies and on the agency issues between ownership and management, while many of the firms in our sample are closely held so that the main agency problem is between large and small shareholders.

The plan of the paper is as follows. Section 2 develops a simple theoretical model dealing with the design of corporate governance institutions under moral hazard. Section 3 describes our data set and methodology, and presents an empirical analysis of governance institutions for Italian listed firms. Section 4 concludes. 


\section{Governance institutions as a commitment de- vice: a simple model}

We consider a common knowledge setup in which a representative entrepreneur, denoted by $E$, owns an entirely equity financed firm of value $V=V_{\max }-C(B)$, where $V_{\max }$ indicates the value of the firm in the absence of private benefits extraction, $B$ denotes $E$ 's private benefits of control and $C(B)-$ with $C^{\prime}(B)>0$ and $C^{\prime \prime}(B)>0$ - is the cost of private benefits extraction. Furthermore, we assume that $0 \leq B \leq \bar{B}$, where $\bar{B} \equiv \gamma F$ with $0<\gamma \leq 1$, and $F$ denotes the firm's free cash flow.

We focus on a situation in which $E$ sells an (exogenous) equity stake $(1-\alpha)$ to external dispersed investors (small shareholders), receiving a revenue denoted by $R$. She however retains control over the firm for any relevant values of her stake $\alpha$. The utility function of the entrepreneur is given by

$$
U(B)+\alpha V+R
$$

where $U(B)$ is assumed to be strictly concave, and $U(0)=0$. Note that the value of $B$ is established after issuing equity, as we assume that it can not be contracted ex ante due to the incompleteness of contracts.

The assumption that the entrepreneur raises external funds in the form of equity enables us to focus directly on the conflict of interest between controlling and minority shareholders. The entrepreneur is interested in maximizing the value of the firm, at the same time maximizing her own private benefits of control. The extraction of private benefits comes at a cost, which induces a reduction of the firm value. The scope for the extraction of private benefits is larger the higher is the firm's free cash flow, which is a measure of the funds available for discretionary use not being committed to any specific purpose (see Jensen, 1986). To capture this effect in the simplest possible way, we assume that there is an upper bound to the possibility of extracting private benefits, modeled as a fraction of the firm's free cash flow. The information regarding private benefits is typically not verifiable or too complex to be described in details, so that financial contracts cannot prescribe a specific level of $B$, which creates a moral hazard 
issue.

External investors are risk neutral and, due to competition among them, they demand an expected return equal to the riskless rate of interest, which we normalize to zero.

After having issued equity, the entrepreneur takes $R$ as given and solves

$$
\max _{0 \leq B \leq \bar{B}} U(B)+\alpha\left[V_{\max }-C(B)\right],
$$

which is a concave problem. Therefore, the unique interior solution of the problem is given by the first order condition

$$
U^{\prime}\left(B^{*}\right)=\alpha C^{\prime}\left(B^{*}\right)
$$

which is necessary and sufficient for a maximum. Hence, the equilibrium level of private benefits is

$$
B_{E}=\left\{\begin{array}{l}
B^{*} \text { if } B^{*}<\bar{B} \\
\bar{B} \text { otherwise }
\end{array}\right.
$$

By applying the implicit function theorem, it is immediate to see that (3) implicitly defines $B^{*}$ as a decreasing function of $\alpha$, so that $B_{E}$ is decreasing in $\alpha$ in the interior solution case, and unaffected by $\alpha$ in the corner solution case. To the contrary, given that $\bar{B}$ is increasing in $F$ by definition, $B_{E}$ is increasing in $F$ in the corner solution case and unaffected by $F$ in the interior solution case. We can summarize the above discussion through the following

Proposition 1 The equilibrium level of private benefits $B_{E}$ is a non-increasing function of $\alpha$ and a non-decreasing function of $F$.

According to Proposition 1, the separation between ownership (partly transferred to small outside shareholders) and control (fully retained by the entrepreneur) leads to an excessive level of private benefits. The entrepreneur is induced to increase her own private benefits, as she is able to shift part of their marginal cost to small shareholders, while retaining the full marginal utility - which is the well known result of Jensen and Meckling (1976). Furthermore, the incentive distortion is stronger the higher the values of the free cash flow, as a larger $F$ makes it easier for $E$ to extract private benefits. 
To evaluate the agency costs induced by the presence of moral hazard, it is useful to compute the utility level achieved by $E$ in the benchmark case of complete contracts, and then compare it with that under contractual incompleteness. If contracts were complete, $E$ would be able to commit to a specific level of $B$ before issuing equity, and to take into account how this level affects the selling price of equity: $R=(1-\alpha)\left[V_{\max }-C(B)\right]$. Hence, her decision problem would be

$$
\max _{0 \leq B \leq \bar{B}} U(B)+\alpha\left[V_{\max }-C(B)\right]+R=U(B)+V_{\max }-C(B) .
$$

Therefore, $E$ would set the level of $B$ as if she retained the whole equity of the firm. The interior solution of Problem (5) is given by

$$
U^{\prime}(\hat{B})=C^{\prime}(\hat{B})
$$

and E's utility level is

$$
U(\hat{B})+V_{\max }-C(\hat{B}) .
$$

We focus on the interior solution case only, as it is natural to assume that $\hat{B}<\bar{B}$. Otherwise, the agency problem does not emerge since the first best solution for $B$ coincides with the equilibrium solution $\bar{B}$ because $B^{*}>\hat{B}$.

However, the first best solution is precluded by the incompleteness of contracts. Since she can not commit ex ante, $E$ sets the level of $B$ after selling equity, hence taking the price as given. Investors anticipate the equilibrium level of private benefits $B_{E}$, which is incorporated into the selling price of equity $R^{*}=(1-\alpha)\left\{V_{\max }-C\left(B_{E}\right)\right\}$. Therefore, the equilibrium level of $E$ 's utility is given by

$$
U\left(B_{E}\right)+\alpha\left\{V_{\max }-C\left(B_{E}\right)\right\}+R^{*}=U\left(B_{E}\right)+V_{\max }-C\left(B_{E}\right) .
$$

By taking the difference between the optimal level of utility (Equation 7)) and the equilibrium one (Equation (8)), we can write the agency cost as

$$
A C=C\left(B_{E}\right)-C(\hat{B})-\left\{U\left(B_{E}\right)-U(\hat{B})\right\}>0
$$

that is positive by definition, since $\hat{B}$ is the argmax of (5). Therefore, the entrepreneur bears the full cost of the incentive distortion created by the ability to extract private benefits. 
The following proposition studies the relationship between the agency cost and the share of equity retained by the entrepreneur, as well as the firm's free cash flow.

Proposition 2 The agency cost $A C$, defined in Equation (9), is non-increasing in $\alpha$ and non-decreasing in $F$.

Proof. Focus on the interior solution case in which $B_{E}=B^{*}$. By differentiating $A C$ with respect to $\alpha$, we get

$$
\left.\frac{d A C}{d \alpha}\right|_{B=B^{*}}=\left(\frac{d C\left(B^{*}\right)}{d B^{*}}-\frac{d U\left(B^{*}\right)}{d B^{*}}\right) \frac{d B^{*}}{d \alpha},
$$

which, recalling that $\frac{d U\left(B^{*}\right)}{d B^{*}}=\alpha \frac{d C\left(B^{*}\right)}{d B^{*}}$, can be rewritten as

$$
\frac{d A C}{d \alpha}=(1-\alpha) \frac{d C\left(B^{*}\right)}{d B^{*}} \frac{d B^{*}}{d \alpha}<0
$$

since $(1-\alpha) \frac{d C\left(B^{*}\right)}{d B^{*}}>0$ by assumption and $\frac{d B^{*}}{d \alpha}<0$, as shown above. As for the corner solution, in which $B_{E}=\bar{B}$, it is immediate to see that the agency cost is not affected by $\alpha$. This proves the first part of the proposition.

To show that $A C$ is non-decreasing in $F$, first observe that $B^{*}$ does not depend on $F$. Turning to the corner solution $B_{E}=\bar{B}$, one has

$$
\left.\frac{d A C}{d F}\right|_{B=\bar{B}}=\left(\frac{d C(\bar{B})}{d \bar{B}}-\frac{d U(\bar{B})}{d \bar{B}}\right) \frac{d \bar{B}}{d F}=\left(\frac{d C(\bar{B})}{d \bar{B}}-\frac{d U(\bar{B})}{d \bar{B}}\right) \gamma
$$

Since $\frac{d C(\hat{B})}{d B}=\frac{d U(\hat{B})}{d B}$, it must be that $\frac{d C(\bar{B})}{d B}>\frac{d U(\bar{B})}{d B}$ because $\frac{d^{2} U(B)}{d B^{2}}<0$ and $\frac{d^{2} C(B)}{d B^{2}}>0$. Hence, one has $\frac{d A C}{d F}>0$, which completes the proof of the proposition.

Proposition 2 shows that the agency cost (weakly) increases in the share $(1-\alpha)$ of equity sold to dispersed shareholders and in the level of the free cash flow. As expected, the agency cost - due to an excessive extraction of private benefits - is increasing in the equilibrium level of private benefits. The latter in turn increases with $(1-\alpha)$ and $F$ (as it has been shown in Proposition 1). It follows that, in equilibrium, the cost of the incentive distortion is higher the lower is the fraction of equity retained by the entrepreneur, and the larger is the scope for the extraction of private benefits as measured by the free cash flow. 
In recent years, an increasing role has been assigned to 'independent' directors, who are supposed to act in the interest of all shareholders by reducing the possibility that the private benefits of large shareholders prevail over the maximization of the firm value.By allowing for the presence of a large share of independent directors in the board, an entrepreneur can commit to let the general interest of shareholders prevail over her own private benefits.

We introduce this issue into the model by assuming that, before issuing equity, $E$ can adopt a governance institution $I$ such that the decision over $B$ is delegated to a third party who maximizes $U(B)+V$. By adopting the governance institution - e.g., by allowing for a strong independent component within the board - E implicitly commits to leave the decision over the level of private benefits to someone who acts as if he were the full owner of the firm. This is equivalent to a commitment for setting $B=\hat{B} .^{1}$

The cost of this commitment is that the third party, entitled to decide over $B$, can also interfere with the firm's management and impose constraints on investment decisions. As a consequence, the governance institution may cause inefficiencies in board's decision making (e.g., by possibly turning down some good investment opportunities). To model this circumstance, we assume that the adoption of the governance institution entails an interference cost $K$, with $K$ strictly larger than zero. Thus, a governance institution is adopted if and only if

$$
A C>K
$$

On the one hand, by adopting the institution the entrepreneur avoids the agency cost, due to her ability to extract private benefits of control. On the other hand, she incurs in the interference cost $K$. Therefore, we can state the following proposition, the proof of which follows immediately from Proposition 2 and Condition (10).

Proposition 3 The incentive for the entrepreneur to adopt the governance institution $I$ is non-increasing in $\alpha$ and non-decreasing in F.

\footnotetext{
${ }^{1}$ It seems natural to assume that $E$ has to decide whether to adopt the institution before issuing equity, reflecting the fact that the design of the governance rules is a long run decision, which cannot easily be modified afterwards.
} 
The higher is the equity share retained by the entrepreneur, the lower is the agency cost of private benefits, since her own incentives are better aligned with those of the other shareholders. Hence, the gain from adopting the governance institution is lower as well. To the contrary, a larger scope for private benefit extraction, measured by $F$, makes the agency problem more severe, which increases the incentives to adopt a governance institution.

\section{Empirical analysis}

We can identify the governance institution limiting the extraction of private benefits with the presence of independent members and of minority representatives in the board. Thus, the theoretical model of the previous section leads to clear testable propositions. In particular, based on Proposition 3, we expect that the degree of board independence is (1) decreasing in ownership concentration, and (2) increasing in the free cash flow.

Additionally, our theoretical model predicts that the governance institution should improve firms' performance and value, as it is adopted only when the agency cost that it would allow to avoid exceeds the interference and coordination costs associated with setting-up the institution.

The empirical analysis of this section is primarily aimed at testing these statements. In doing so, however, we are able to derive additional evidence on the corporate governance of Italian listed firms and on its links with firms' performance, going beyond the direct implications of the theoretical model.

\subsection{Dataset and methodology}

Our econometric analysis is based on a balanced panel of 157 firms listed in the Italian stock exchange over the period 2004-2007, collecting information on board and ownership structure, as well as on firms' characteristics and performance. A list of the variables included in the dataset, with the corresponding data sources and descriptive statistics, is given in the Appendix Table. ${ }^{2}$

\footnotetext{
${ }^{2}$ Analogous exercises conducted on the unbalanced panel of all listed Italian firms for the same time interval lead to results that are fully consistent with those reported in the paper.
} 
Our panel entails very little time-series (i.e. within-subject) information, as there is an extremely limited variability over time among all the board and ownership structure data included in our sample. Therefore, our econometric exercises essentially exploit only the cross-sectional dimension of the panel. For this reason, we resort to pooled cross-section regressions running time fixed effects by means of a set of time dummy variables, and checking for the presence of cluster effects. The resulting cluster-robust standard errors provide overall the same information on the statistical significance of the estimated coefficients as those reported in the tables.

\subsection{Ownership concentration and board composition}

The first testable implication of our theoretical model concerns the negative expected relationship between board independence and ownership concentration. Tables 1 and 2 provide strong evidence in this direction.

\section{[INSERT TABLES 1 AND 2 ABOUT HERE]}

The first row of Table 1 shows that the share of executive members in a board increases with ownership concentration, consistently with the theoretical model. Table 2 (first row) shows that the likelihood of observing the presence of a minority list in the election of the board is decreasing in ownership concentration.

Family ownership plays a role that is similar to that of ownership concentration: the control over a 'family firm' is typically shared among a few individuals belonging to the same family, which enhances the concentration of power in the hands of a few large shareholders pursuing the same interest. Therefore, we may expect that the family ownership dummy affects the dependent variables in quite the same way as ownership concentration. Indeed, family ownership leads to boards with a larger share of executive members and less independent members and minority representatives (see Table 1), as well as to a smaller probability of observing executive and compensation committees (see Table 2).

Estimates are available from the authors upon request. 
We also find that firms having concentrated ownership and family firms appear having smaller boards, with fewer independent members and minority representatives included in the board. We may interpret this as evidence that controlling owners prefer smaller boards in which executives play a key role, in order to improve efficiency and to avoid the coordination problems affecting large boards. ${ }^{3}$ Similar considerations apply to committees, which are less likely to be present when ownership concentration is higher.

Our evidence shows that the widely used shareholders' agreements play a significant role in shaping the boards of Italian listed firms. ${ }^{4}$ These agreements have often the purpose of reaching a specific composition of the board of directors, where each participant is entitled to appoint a given number of directors. Table 1 (third row) shows that boards include a larger fraction of non-executive nonindependent members in firms where an agreement is present than in other firms. Indeed, these directors presumably represent the large shareholders participating in the agreement. Furthermore, Table 2 (third row) shows that the existence of a shareholders' agreement increases the probability that an executive committee is present, pointing to the possibility that executive committees act as bodies where the coordination among the participants in the agreement takes place.

It is also interesting to note that the percentage of female members over total directors is on average about $4 \%$ higher in family firms than in other firms, which may be interpreted as indirect evidence of women's difficulties in reaching key positions in Italian corporations. These difficulties appear to be lower in family firms, where family members are more likely to be appointed as directors regardless of their gender, thus increasing the probability that a woman is included in the board.

Finally, all regressions in Tables 1 and 2 have been run by adding controls for specific sectors, finding that the sector of activity plays a significant role in

\footnotetext{
${ }^{3}$ See Kim (2011) on the relationship between board size and directors' turnover.

${ }^{4}$ Agreements of this type are diffused also in other European countries as a mean to deviate from the one-share-one-vote principle; see EU (2007). For analyses of the effects of shareholders'agreements on the governance of Italian firms, see e.g. Baglioni (2010).
} 
shaping the characteristics of the board. ${ }^{5}$ Three observations are of particular interest. First, the boards of high tech firms are smaller and with a larger share of executive members, most likely because of the strategic advising role of directors: in high tech firms the need of specific knowledge, embodied in executives, is presumably larger than in other sectors. Second, financial firms have large boards with a significant fraction of independent members, which reduces the weight of executive members. This is probably due to the fact that most large Italian banks and insurance companies are at the core of a wide network of cross-ownerships and cross-directorships, involving also non-financial firms. Therefore, there is the need to adequately represent the interests of several relevant shareholders. The large size of the board may be, in turn, at the origin of the widespread use of executive committees in financial firms, as a way to improve the efficiency of the decision process, and to preserve the role of top managers within the board. ${ }^{6}$ Third, the composition of the boards of utilities seems to reflect the prominent role of public ownership in this industry: more than half of the utilities included in our sample have in fact the public sector (either the central government, or municipalities) as their main stockholder. The public nature of utilities may help explaining the inclusion of many independent and minority members in the board, as representatives of the composite interests of the public shareholders.

\subsection{Free cash flow and board composition}

The second testable implication of our theoretical model concerns the positive relationship between the degree of board independence and firms' free cash flow. Our empirical evidence strongly supports this theoretical prediction: as the free cash flow grows larger, the board composition shifts in favor of independent members (see Table 3).

\footnotetext{
${ }^{5}$ The affiliation of a firm to a specific sector is based on the ICB code of each firm, as reported by Datastream.

${ }^{6}$ Agostino et $\mathrm{Al}$. (2005) investigate the relationship between ownership concentration and performance for Italian banks, finding that where ownership is more concentrated (abnormal) profits tend to be larger.
} 


\section{[INSERT TABLES 3 AND 4 ABOUT HERE]}

In order to assess the ceteris paribus effect of the free cash flow on corporate governance, we control for firms' characteristics - namely, market value and growth opportunities - that are likely to exert additional effects on board structure. Table 3 shows the existence of a positive effect of firm size on the number of board members: the higher is the market value of a firm (a typical proxy for firm size), the larger is the size of its board. However, the impact of firm size is non-linear, indicating that as firm size grows, board size increases as well, but at a decreasing rate. Larger boards are able to include more (controlling and minority) representatives of shareholders: the coefficients of non-executive non-independent members and of minority members are both positive and significant. As a consequence, the share of executive members is decreasing in firm size. Larger boards are also more likely to be organized in committees in order to improve the efficiency of the decision process. Table 4 confirms that the probability of observing compensation and audit committees is increasing in firm size.

Turning to growth opportunities, measured by the market-to-book ratio, they call for specific knowledge to be fully exploited. Table 3 confirms that where such opportunities are more relevant the composition of boards shifts in favor of executive members, who are typically more endowed with specific skills.

Finally, the inclusion of controls for the specific features of different industries leads to results (see Tables $3-4$ ) that are very much in line with those already shown in Tables 1-2.

\subsection{Board composition and firms' performance}

The third testable implication of our theoretical model is that firms adopt a governance institution whenever the benefits from doing so exceed the associated costs in terms of interference and coordination problems. Hence, one would expect that when a governance institution is adopted, performance and consequently firms' value improve. The econometric exercises shown in Table 5 do not support this conclusion. 
To the contrary, it appears that firms' performance is negatively affected by the share of independent members in the board, while it is positively affected by the share of executive members. This suggests that executives, by bringing specific knowledge, contribute to the efficiency of the decision process. Independent members, on the other hand, play mainly a monitoring role, so that all shareholders are represented and the extraction of private benefits by dominant owners is limited. This role may sometimes reduce the speed and efficiency of the board decision making process. Independent members may therefore be included in the board even when the cost of keeping under control the agency issue exceeds its benefit. This result is not consistent with our theoretical model, which suggests instead that governance institutions should not be adopted when it is too costly. However, at least two interpretations of this empirical finding may be proposed. The first is based on the effects of (self-)regulatory mechanisms (such as the Code of Conduct for listed companies) that may constrain the design of governance institutions, forcing listed firms to introduce an inefficiently large independent component in their boards. The second deals with the implications of reputational concerns that, even in the absence of explicit regulatory constraints, may induce some corporations to sub-optimally add independent directors.

Interestingly, the presence of a minority list seems to have a positive impact on the market value of firms (as measured by the market-to-book ratio), suggesting that the market appreciates the introduction of an institution aimed at protecting the interests of small shareholders. The same does not hold true for independent members, suggesting that financial markets consider the directors appointed by minority owners as being more effective than independent directors.

Our econometric specifications also provide indications on the use of committees in the organization of the board. In particular, on the one hand, the presence of an executive committee improves the efficiency of the decision process by separating the decision and the monitoring role of directors, leading in this way to a better performance. On the other hand, the presence of a compensation committee seems to increase risk (as proxied by the standard deviation of the 
share price), possibly due to the adoption of compensation policies introducing convex wage schedules (e.g., stock options), increasing managerial incentives to take risky strategies. ${ }^{7}$

We finally control for the effect of board size on firms' performance. On the one hand, the addition of a new member to the board should have a positive effect regardless of her role: if an executive member, she provides specific skills improving the advisory role of the board; if an independent/minority member, she introduces an additional source of protection for small shareholders improving the monitoring role of the board. On the other hand, however, the inclusion of additional members beyond some threshold level might reduce the efficiency of the decision process by exacerbating coordination problems. Our estimates highlight the existence of such a trade-off: both the performance measures we consider ROA and EBIT/assets - and the market-to-book ratio are increasing in board size, but the relationship is non-linear, pointing to a negative impact of board size beyond some threshold level.

\section{Concluding remarks}

The empirical evidence we provide in this paper supports the prediction of our theoretical model, confirming the view that corporate boards are designed in order to efficiently cope with the agency issues arising from the separation between ownership and control. To summarize our main results, we find that governance institutions aimed at protecting the general interest of shareholders - like independent directors, minority representatives and committees - are used more extensively where agency problems are more severe. In particular, we show that board composition favors independent members in firms where the free cash flow is larger. Conversely, it favors executive members in firms where ownership is more concentrated. Family ownership plays a role similar to that of ownership concentration, leading to boards with a large percentage of executive members.

\footnotetext{
${ }^{7}$ See Baglioni and Colombo (2009) for a discussion of the role of options in managerial compensation and, more specifically, Ross (2004) for the effects of options on managers' risktaking attitudes.
} 
As for the relationship between firm value and corporate governance, we find on the one hand that executive members exert a positive effect on performance, which is consistent with the view that executives - by bringing specific knowledge - contribute to the efficiency of the decision process. On the other hand, independent members seem to negatively affect performance, suggesting that their monitoring role may reduce the efficiency of the board decision making process. This is somewhat puzzling, as it suggests that owners are willing to setup governance institutions favoring independent directors even when the cost of doing so exceeds the gains ensuing from their monitoring role, possibly due to the impact of (self-)regulatory constraints and/or reputational concerns. Better understanding this issue is a goal for future research.

Our empirical analysis also highlights a remarkable heterogeneity across firms in the adoption of governance institutions, depending on specific characteristics of corporations such as the degree of ownership concentration and the level of free cash flow. We have shown that the diverse governance mechanisms adopted by different firms are consistent with the objective of minimizing agency costs. In this perspective, the paper has a strong policy implication, namely that the regulatory approach should not be one that imposes a detailed set of rules about the design of governance institutions. It should instead be aimed at providing a sufficiently general regulatory framework within which firms remain free to design their governance as an optimal response to their specific features.

\section{References}

Adams, R.B. and D. Ferreira, 2007. A Theory of Friendly Boards. Journal of Finance 62, 217-250.

Agostino, M., L. Leonida and F. Trivieri, 2005. Profits Persistence and Ownership: Evidence from the Italian Banking Sector. Applied Economics 37(14), 1615-1621.

Baglioni, A., 2010. Shareholders' Agreements and Voting Power. Evidence from Italian listed firms. Applied Economics, in press.

Baglioni, A. and L. Colombo, 2009. Managers' Compensation and Misreporting: 
A Costly State Verification Approach. Economic Inquiry 47, 278-289.

Boone, A., Field, L., Karpoff, J. and C. Raheja, 2007. The Determinants of Corporate Board Size and Composition: An Empirical Analysis. Journal of Financial Economics 85, 66-101.

Coles, J., D. Naveen and L. Naveen, 2008. Boards: Does One Size Fit All?. Journal of Financial Economics 87, 329-356.

Del Brio, E.B., E.L. Maia-Ramires and A. De Miguel, 2011. Ownership Structure and Diversification in a Scenario of Weak Shareholder Protection. Applied Economics, in press.

EU, 2007. Report on the Proportionality Principle in the European Union. External study commissioned by the European Commission, Final Report.

Harris, M and A. Raviv, 2008. A Theory of Board Control and Size. Review of Financial Studies, 21, 1797-1832.

Jensen, M. (1986), Agency costs of free cash flow, corporate finance, and takeovers, American Economic Review, 76 (2), 323-329.

Jensen, M. and W. Meckling, 1976. Theory of the Firm: Managerial Behavior, Agency Costs and Ownership Structure. Journal of Financial Economics 3, 305360.

Kim, D., 2011. On the Determinants of Director Additions and Removals. Applied Economics, in press.

Lehn, K., Patro, S. and M. Zhao, 2009. Determinants of the Size and Composition of US Corporate Boards: 1935-2000. Financial Management 38, 747-780.

Linck, J.S., Netter, J.M. and T. Joung, 2007. The Determinants of Board Structure. Journal of Financial Economics 87, 308-328.

Ross, S., 2004. Compensation, Incentives, and the Duality of Risk Aversion and Riskiness. Journal of Finance 59, 207-225. 
TABLE 1. Ownership concentration and board composition

\begin{tabular}{|c|c|c|c|c|c|c|c|c|c|c|c|c|}
\hline \multirow{3}{*}{$\begin{array}{l}\text { Independent Variable } \\
\text { Top } 3 \text { shareholders ownership share (\%) }\end{array}$} & \multicolumn{12}{|c|}{ Dependent variables } \\
\hline & \multicolumn{2}{|c|}{\begin{tabular}{|c|}
$\begin{array}{c}\text { Executive members } \\
(\%)\end{array}$ \\
\end{tabular}} & \multicolumn{2}{|c|}{$\begin{array}{c}\text { Independent members } \\
(\%)\end{array}$} & \multicolumn{2}{|c|}{$\begin{array}{c}\text { Non-executive } \\
\text { non-indep. members (\%) }\end{array}$} & \multicolumn{2}{|c|}{$\begin{array}{c}\text { Minority members } \\
(\%)\end{array}$} & \multicolumn{2}{|c|}{$\begin{array}{c}\text { Board size } \\
\text { (number of members) }\end{array}$} & \multicolumn{2}{|c|}{$\begin{array}{c}\text { Female members } \\
(\%)\end{array}$} \\
\hline & $\begin{array}{l}0.172^{\star \star *} \\
(0.035)\end{array}$ & $\begin{array}{c}0.175^{\star * *} \\
(0.040)\end{array}$ & $\begin{array}{l}-0.207^{\star \star \star} \\
(0.052)\end{array}$ & $\begin{array}{c}-0.210^{\star * *} \\
(0.055)\end{array}$ & $\begin{array}{c}0.038 \\
(0.051)\end{array}$ & $\begin{array}{c}0.040 \\
(0.051)\end{array}$ & $\begin{array}{l}-0.028 \\
(0.026)\end{array}$ & $\begin{array}{l}-0.012 \\
(0.024)\end{array}$ & $\begin{array}{c}-0.048^{\star * *} \\
(0.008)\end{array}$ & $\begin{array}{c}-0.055^{\star \star *} \\
(0.009)\end{array}$ & $\begin{array}{c}0.005 \\
(0.014)\end{array}$ & $\begin{array}{l}0.008 \\
(0.143)\end{array}$ \\
\hline Family ownership (dummy) & $\begin{array}{l}5.473^{\star \star \star} \\
(1.382)\end{array}$ & $\begin{array}{l}7.093^{\star \star \star} \\
(1.435)\end{array}$ & $\begin{array}{l}-2.071 \\
(1.485)\end{array}$ & $\begin{array}{c}-4.648^{\star \star \star} \\
(1.495)\end{array}$ & $\begin{array}{l}-3.874^{\star \star} \\
(1.853)\end{array}$ & $\begin{array}{l}-2.775 \\
(1.770)\end{array}$ & $\begin{array}{l}-1.672^{\star \star} \\
(0.727)\end{array}$ & $\begin{array}{l}-2.903^{\star \star \star} \\
(0.725)\end{array}$ & $\begin{array}{c}-1.278^{\star \star *} \\
(0.274)\end{array}$ & $\begin{array}{l}-1.685^{\star \star *} \\
(0.292)\end{array}$ & $\begin{array}{c}4.138^{\star \star \star} \\
(0.687)\end{array}$ & $\begin{array}{c}3.544^{\star \star \star} \\
(0.720)\end{array}$ \\
\hline Shareholders agreements (dummy) & $\begin{array}{l}-1.889 \\
(1.962)\end{array}$ & $\begin{array}{l}-2.274 \\
(2.114)\end{array}$ & $\begin{array}{l}-3.448^{\star} \\
(2.113)\end{array}$ & $\begin{array}{l}-2.402 \\
(2.181)\end{array}$ & $\begin{array}{l}4.824^{\star *} \\
(2.315)\end{array}$ & $\begin{array}{l}4.014^{*} \\
(2.333)\end{array}$ & $\begin{array}{c}0.113 \\
(1.100)\end{array}$ & $\begin{array}{c}0.360 \\
(1.130)\end{array}$ & $\begin{array}{l}1.099^{\star \star \star} \\
(0.353)\end{array}$ & $\begin{array}{l}1.338^{\star \star \star} \\
(0.392)\end{array}$ & $\begin{array}{c}-1.500 * * \\
(0.645)\end{array}$ & $\begin{array}{c}-1.315^{\star \star} \\
(0.649)\end{array}$ \\
\hline Dummy High Tech & $\begin{array}{l}13.648^{\star \star \star} \\
(3.100)\end{array}$ & & $\begin{array}{l}-2.529 \\
(2.664)\end{array}$ & & $\begin{array}{c}-12.803^{\star \star \star} \\
(3.184)\end{array}$ & & $\begin{array}{l}0.594 \\
(1.151)\end{array}$ & & $\begin{array}{c}-2.155^{\star \star \star} \\
(0.348)\end{array}$ & & & $\begin{array}{l}0.320 \\
(1.133)\end{array}$ \\
\hline Dummy Financials & $\begin{array}{l}-9.026^{\star \star \star} \\
(1.591)\end{array}$ & & $\begin{array}{l}9.647^{\star \star \star} \\
(2.136)\end{array}$ & & $\begin{array}{l}-1.200 \\
(2.179)\end{array}$ & & $\begin{array}{c}1.213 \\
(1.168)\end{array}$ & & $\begin{array}{l}3.089 * \star \star \\
(0.390)\end{array}$ & & & $\begin{array}{c}-1.527^{* *} \\
(0.669)\end{array}$ \\
\hline Dummy Utilities & $\begin{array}{l}-10.011^{\star \star \star} \\
(2.042)\end{array}$ & & $\begin{array}{l}15.031^{\star \star \star} \\
(4.242)\end{array}$ & & $\begin{array}{l}-4.938 \\
(4.249)\end{array}$ & & $\begin{array}{c}12.075^{\star \star \star} \\
(2.901)\end{array}$ & & $\begin{array}{c}0.543 \\
(0.454)\end{array}$ & & & $\begin{array}{c}-4.519 * \star \star \\
(0.582)\end{array}$ \\
\hline Constant & $\begin{array}{l}20.669^{\star \star \star \star} \\
(2.523)\end{array}$ & $\begin{array}{c}18.698^{\star \star \star} \\
(2.716)\end{array}$ & $\begin{array}{l}50.973^{\star \star \star \star} \\
(3.545)\end{array}$ & $\begin{array}{c}54.664^{\star \star \star} \\
(3.709) \\
\end{array}$ & $\begin{array}{c}28.705^{\star \star \star} \\
(3.560)\end{array}$ & $\begin{array}{c}26.507^{\star \star \star} \\
(3.388)\end{array}$ & $\begin{array}{l}4.397^{\star \star} \\
(1.867)\end{array}$ & $\begin{array}{c}4.891^{\star \star \star} \\
(1.614)\end{array}$ & $\begin{array}{c}12.890^{\star \star \star *} \\
(0.564)\end{array}$ & $\begin{array}{c}13.931 * \star \star \\
(0.646)\end{array}$ & $\begin{array}{c}3.279^{\star \star \star} \\
(1.009) \\
\end{array}$ & $\begin{array}{c}3.854^{\star \star \star} \\
(1.041)\end{array}$ \\
\hline Year dummies & Yes & Yes & Yes & Yes & Yes & Yes & Yes & Yes & Yes & Yes & Yes & Yes \\
\hline Nr.Obs. & 628 & 628 & 628 & 628 & 628 & 628 & 628 & 628 & 628 & 628 & 628 & 628 \\
\hline R-sq. & 0.192 & 0.077 & 0.113 & 0.054 & 0.045 & 0.016 & 0.093 & 0.028 & 0.294 & 0.148 & 0.078 & 0.097 \\
\hline $\begin{array}{l}F \\
{[p \text {-value }]}\end{array}$ & $\begin{array}{c}18.09 \\
{[0.000]}\end{array}$ & $\begin{array}{c}10.05 \\
{[0.000]}\end{array}$ & $\begin{array}{c}6.41 \\
{[0.000]}\end{array}$ & $\begin{array}{c}4.45 \\
{[0.000]}\end{array}$ & $\begin{array}{c}2.88 \\
{[0.002]}\end{array}$ & $\begin{array}{c}1.72 \\
{[0.114]}\end{array}$ & $\begin{array}{c}4.94 \\
{[0.000]}\end{array}$ & $\begin{array}{c}4.21 \\
{[0.000]}\end{array}$ & $\begin{array}{c}23.53 \\
{[0.000]}\end{array}$ & $\begin{array}{c}16.28 \\
{[0.000]}\end{array}$ & $\begin{array}{c}9.10 \\
{[0.000]}\end{array}$ & $\begin{array}{c}22.93 \\
{[0.000]}\end{array}$ \\
\hline
\end{tabular}

Robust standard errors in parenthesis. 
TABLE 2. Ownership concentration and board committees

\begin{tabular}{|c|c|c|c|c|c|c|c|c|}
\hline \multirow{3}{*}{\begin{tabular}{|l|} 
Independent Variable \\
Top 3 shareholders (\%) ownership share (\%)
\end{tabular}} & \multicolumn{8}{|c|}{ Dependent variables } \\
\hline & \multicolumn{2}{|c|}{ Executive Committee } & \multicolumn{2}{|c|}{ Compensation Committeee } & \multicolumn{2}{|c|}{ Audit Committee } & \multicolumn{2}{|c|}{ Minority list } \\
\hline & $\begin{array}{c}-0.002^{\star \star \star} \\
(0.001)\end{array}$ & $\begin{array}{c}-0.003^{\star \star \star} \\
(0.001)\end{array}$ & $\begin{array}{c}-0.007^{\star \star \star} \\
(0.001)\end{array}$ & $\begin{array}{c}-0.006^{\star \star \star} \\
(0.001)\end{array}$ & $\begin{array}{c}-0.004^{\star * *} \\
(0.001)\end{array}$ & $\begin{array}{c}-0.004^{\star * \star} \\
(0.001)\end{array}$ & $\begin{array}{l}-0.004^{\star \star \star} \\
(0.001)\end{array}$ & $\begin{array}{c}-0.003^{\star * *} \\
(0.001)\end{array}$ \\
\hline Family ownership (dummy) & $\begin{array}{c}-0.178^{\star \star \star} \\
(0.031)\end{array}$ & $\begin{array}{c}-0.201^{\star \star *} \\
(0.028)\end{array}$ & $\begin{array}{c}-0.124^{\star \star \star} \\
(0.037)\end{array}$ & $\begin{array}{c}-0.115^{\star \star \star} \\
(0.036)\end{array}$ & $\begin{array}{l}-0.040 \\
(0.029)\end{array}$ & $\begin{array}{l}-0.041 \\
(0.029)\end{array}$ & $\begin{array}{l}-0.001 \\
(0.047)\end{array}$ & $\begin{array}{l}-0.049 \\
(0.045)\end{array}$ \\
\hline Shareholders agreements (dummy) & $\begin{array}{l}0.073^{\star} \\
(0.042)\end{array}$ & $\begin{array}{l}0.097^{\star \star} \\
(0.043)\end{array}$ & $\begin{array}{l}-0.055 \\
(0.045)\end{array}$ & $\begin{array}{l}-0.065 \\
(0.045)\end{array}$ & $\begin{array}{c}0.007 \\
(0.033)\end{array}$ & $\begin{array}{c}0.006 \\
(0.034)\end{array}$ & $\begin{array}{l}0.015 \\
(0.059)\end{array}$ & $\begin{array}{c}0.030 \\
(0.565)\end{array}$ \\
\hline Dummy High Tech & $\begin{array}{l}-0.065 \\
(0.045)\end{array}$ & & $\begin{array}{c}0.018 \\
(0.059)\end{array}$ & & $\begin{array}{l}-0.019 \\
(0.049)\end{array}$ & & $\begin{array}{l}0.132^{*} \\
(0.079)\end{array}$ & \\
\hline $\begin{array}{l}\text { Dummy Financials } \\
\text { Dummy Utilities }\end{array}$ & $\begin{array}{c}0.313^{\star * \star} \\
(0.044) \\
--\end{array}$ & & $\begin{array}{c}-0.138 * \star \star \\
(0.048) \\
0.105 \\
(0.052)\end{array}$ & & $\begin{array}{c}-0.013 \\
(0.034) \\
0.038 \\
(0.047)\end{array}$ & & $\begin{array}{l}0.014 \\
(0.056) \\
0.435^{\star \star \star} \\
(0.074)\end{array}$ & \\
\hline Year dummies & Yes & Yes & Yes & Yes & Yes & Yes & Yes & Yes $^{\wedge}$ \\
\hline Nr.Obs. & 596 & 628 & 628 & 628 & 628 & 628 & 628 & 628 \\
\hline Pseudo R-sq. & 0.216 & 0.111 & 0.107 & 0.085 & 0.056 & 0.055 & 0.207 & 0.179 \\
\hline Wald Chi-sq. & 106.64 & 54.79 & 70.92 & 52.17 & 23.04 & 20.11 & 148.97 & 140.53 \\
\hline [p-value] & [0.000] & [0.000] & [0.000] & [0.000] & [0.006] & [0.003] & {$[0.000]$} & {$[0.000]$} \\
\hline Log Pseudo-L. & -245.997 & -285.774 & -297.581 & -304.892 & -241.773 & -242.171 & -342.555 & -354.644 \\
\hline
\end{tabular}

Probit models (marginal effects). Robust standard errors in parenthesis.

First column model: no utilities have an executive committee.

$\wedge$ Year dummies 2006 and 2007 positive and statistically significant at the 1\% level 
TABLE 3. Free cash flow and board composition

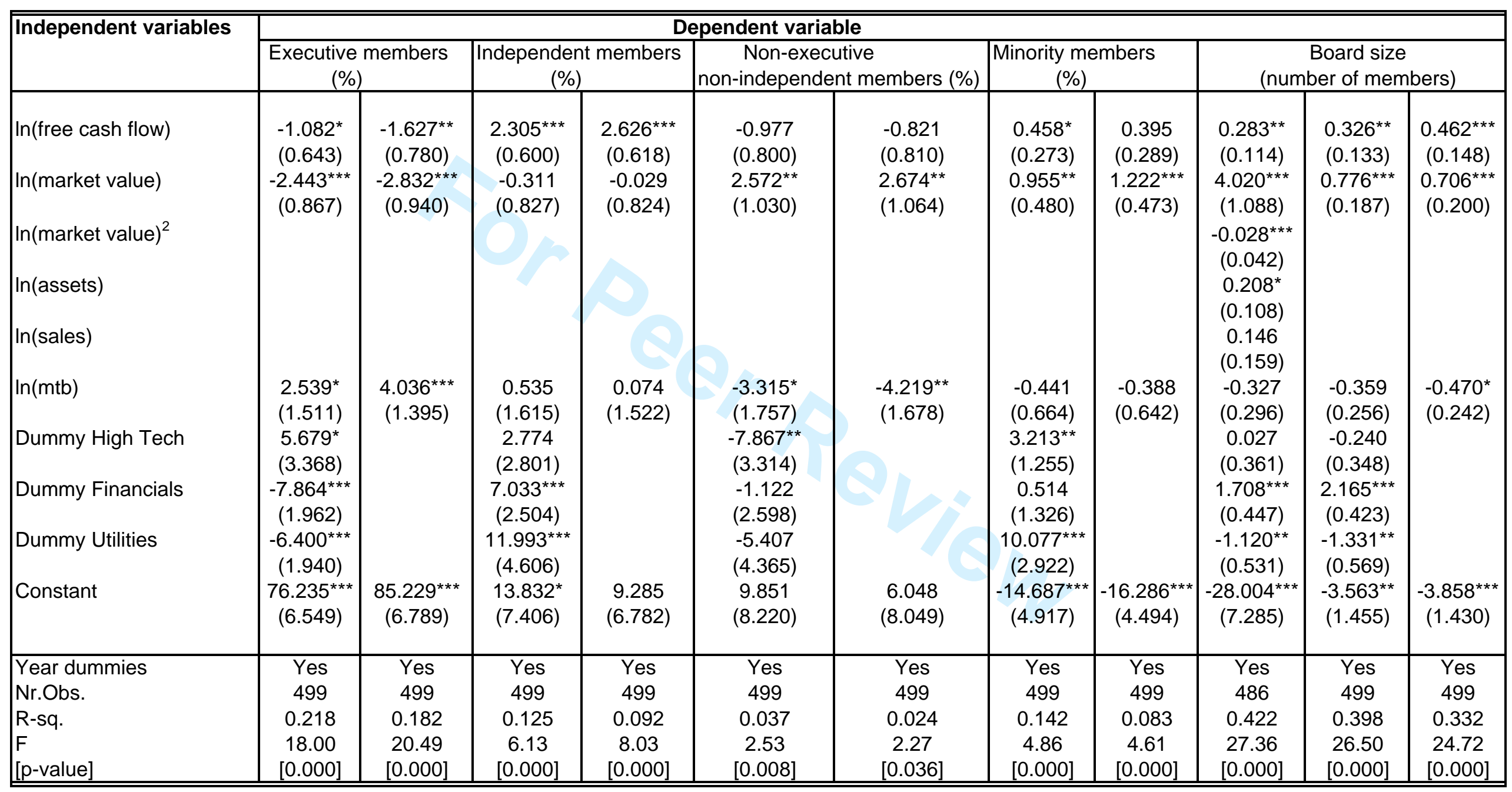

Robust standard errors in parenthesis. 
TABLE 4. Free cash flow and board committees

\begin{tabular}{|c|c|c|c|c|c|c|c|c|}
\hline \multirow[t]{2}{*}{ Independent variables } & \multicolumn{8}{|c|}{ Dependent variable } \\
\hline & \multicolumn{2}{|c|}{ Executive Committee } & \multicolumn{2}{|c|}{ Compensation Committeee } & \multicolumn{2}{|c|}{ Audit Committee } & \multicolumn{2}{|c|}{ Minority list } \\
\hline In(free cash flow) & $\begin{array}{c}0.028^{\star} \\
(0.015)\end{array}$ & $\begin{array}{c}0.051^{\star * *} \\
(0.017)\end{array}$ & $\begin{array}{c}0.015 \\
(0.013)\end{array}$ & $\begin{array}{c}0.002 \\
(0.015)\end{array}$ & $\begin{array}{c}-0.006 \\
(0.010)\end{array}$ & $\begin{array}{l}-0.012 \\
(0.010)\end{array}$ & $\begin{array}{c}-0.015 \\
(0.018)\end{array}$ & $\begin{array}{l}-0.021 \\
(0.018)\end{array}$ \\
\hline $\ln (\mathrm{ma}$ & $\begin{array}{c}0.023 \\
(0.020)\end{array}$ & $\begin{array}{l}-0.005 \\
(0.022)\end{array}$ & $\begin{array}{c}0.054^{\star \star \star} \\
(0.018)\end{array}$ & $\begin{array}{l}0.046^{\star *} \\
(0.020)\end{array}$ & $\begin{array}{c}0.047^{\star \star \star} \\
(0.014)\end{array}$ & $\begin{array}{c}0.046^{\star \star \star} \\
(0.015)\end{array}$ & $\begin{array}{c}0.073^{* \star *} \\
(0.027)\end{array}$ & $\begin{array}{c}0.020^{\star \star \star} \\
(0.027)\end{array}$ \\
\hline $\ln (m t b)$ & $\begin{array}{c}0.023 \\
(0.037)\end{array}$ & $\begin{array}{c}0.014 \\
(0.037)\end{array}$ & $\begin{array}{c}0.063 \\
(0.041)\end{array}$ & $\begin{array}{l}0.091^{\star \star} \\
(0.041)\end{array}$ & $\begin{array}{l}0.063^{\star} \\
(0.034)\end{array}$ & $\begin{array}{l}0.069^{\star} \\
(0.035)\end{array}$ & $\begin{array}{c}0.015 \\
(0.051)\end{array}$ & $\begin{array}{c}0.020 \\
(0.047)\end{array}$ \\
\hline Dummy High Tech & $\begin{array}{c}0.068 \\
(0.079)\end{array}$ & & $\begin{array}{l}0.093^{\star} \\
(0.046)\end{array}$ & & $\begin{array}{c}0.005 \\
(0.044)\end{array}$ & & $\begin{array}{c}0.138 \\
(0.090)\end{array}$ & \\
\hline nancials & $\begin{array}{c}0.342^{\star \star \star} \\
(0.057)\end{array}$ & & $\begin{array}{c}-0.229^{\star \star *} \\
(0.059)\end{array}$ & & $\begin{array}{c}-0.100 * * \\
(0.046)\end{array}$ & & $\begin{array}{c}-0.028 \\
(0.066)\end{array}$ & \\
\hline Dummy Utilities & -- & & $\begin{array}{l}-0.007 \\
(0.079)\end{array}$ & & $\begin{array}{l}-0.075 \\
(0.075)\end{array}$ & & $\begin{array}{c}0.335^{\star \star *} \\
(0.095)\end{array}$ & \\
\hline Yearc & Yes & $\overline{\mathrm{Ye}}$ & $\overline{Y e}$ & Yes & Yes & Yes & Yes & Yes \\
\hline & 467 & 49 & 49 & 499 & 499 & 499 & 499 & 499 \\
\hline & 0.176 & 0.070 & 0.11 & 0.070 & 0.106 & 0.091 & 0.225 & 0.204 \\
\hline Wald Chi-sq. & 86.16 & 31.06 & 47.37 & 32.99 & 31.13 & 27.00 & 124.36 & 119.15 \\
\hline [p-va & [0.000] & {$[0.000]$} & {$[0.000]$} & [0.000] & {$[0.000]$} & {$[0.000]$} & {$[0.000]$} & [0.000] \\
\hline Log Pseudo-L. & -208.099 & -242.471 & -228.342 & -240.123 & -170.811 & -173.853 & -267.632 & -274.976 \\
\hline
\end{tabular}

Probit models (marginal effects). Robust standard errors in parenthesis.

First column model: no utilities have an executive committee.

Last column models: 2006 and 2007 year dummies positive and statistically significant at the 1\% level. 
TABLE 5. Board composition and firm's performance

\begin{tabular}{|c|c|c|c|c|c|c|c|c|}
\hline Independent variables & & & & ependent & ariable & & & \\
\hline & & $A(*)$ & EBIT/Ass & $(\%)(*)$ & $\overline{\mathrm{MTE}}$ & & Stand. dev. & share price \\
\hline Executive members (\%) & $\begin{array}{l}0.041^{*} \\
(0.024)\end{array}$ & $0.044^{\star *}$ & $0.071^{* *}$ & 0.071 *** & 0.008 & 0.014 & $0.008^{* *}$ & $0.011^{\star \star *}$ \\
\hline Independent members (\%) & $\begin{array}{l}-0.022 \\
(0.014)\end{array}$ & $\begin{array}{l}-0.024^{\star} \\
(0.013)\end{array}$ & $\begin{array}{l}-0.029^{*} \\
(0.016)\end{array}$ & $\begin{array}{c}-0.036^{\star *} \\
(0.015)\end{array}$ & $\begin{array}{l}-0.006 \\
(0.005)\end{array}$ & $\begin{array}{l}-0.007 \\
(0.006)\end{array}$ & 0.004 & 0.003 \\
\hline Executive Committee (dummy) & $\begin{array}{l}0.341^{*} \\
(0.201)\end{array}$ & $\begin{array}{c}0.214 \\
(0.231)\end{array}$ & $\begin{array}{c}0.783^{\star * *} \\
(0.275)\end{array}$ & $\begin{array}{l}0.527^{\star *} \\
(0.252)\end{array}$ & $\begin{array}{c}0.091 \\
(0.200)\end{array}$ & $\begin{array}{c}0.090 \\
(0.202)\end{array}$ & $\begin{array}{c}0.063 \\
(0.085)\end{array}$ & $\begin{array}{c}0.053 \\
(0.084)\end{array}$ \\
\hline Compensation Committeee (dummy) & $\begin{array}{l}-0.450 \\
(0.722)\end{array}$ & $\begin{array}{l}-0.178 \\
(0.734)\end{array}$ & $\begin{array}{l}-0.281 \\
(0.817)\end{array}$ & $\begin{array}{c}0.133 \\
(0.811)\end{array}$ & $\begin{array}{l}-0.165 \\
(0.266)\end{array}$ & $\begin{array}{l}-0.049 \\
(0.224)\end{array}$ & $\begin{array}{l}0.157^{\star} \\
(0.093)\end{array}$ & $\begin{array}{l}0.227^{* *} \\
(0.101)\end{array}$ \\
\hline Audit Committee (dummy) & $\begin{array}{l}0.502 \\
(0.678)\end{array}$ & $\begin{array}{c}0.424 \\
(0.687)\end{array}$ & $\begin{array}{c}0.412 \\
(0.887)\end{array}$ & $\begin{array}{c}0.328 \\
(0.903)\end{array}$ & $\begin{array}{c}0.225 \\
(0.276)\end{array}$ & $\begin{array}{c}0.210 \\
(0.291)\end{array}$ & $\begin{array}{c}0.092 \\
(0.099)\end{array}$ & $\begin{array}{c}0.087 \\
(0.106)\end{array}$ \\
\hline Minority list (dummy) & {$\left[\begin{array}{l}-0.762 \\
(0.832)\end{array}\right.$} & $\begin{array}{l}-0.461 \\
(0.716)\end{array}$ & $\begin{array}{c}0.905 \\
(' 0.769)\end{array}$ & $\begin{array}{c}1.143 \\
(0.745)\end{array}$ & $\begin{array}{l}0.491^{*} \\
(0.291)\end{array}$ & $\begin{array}{l}0.594^{*} \\
(0.353)\end{array}$ & $\begin{array}{l}-0.076 \\
(0.136)\end{array}$ & $\begin{array}{c}-0.047 \\
(0.140)\end{array}$ \\
\hline Board size & $\begin{array}{l}0.946^{* *} \\
(0.419)\end{array}$ & $\begin{array}{l}0.948^{\star *} \\
(0.379)\end{array}$ & $\begin{array}{l}0.929 * * \\
(0.383)\end{array}$ & $\begin{array}{l}0.956^{\star \star} \\
(0.376)\end{array}$ & $\begin{array}{c}0.219 \text { *** } \\
(0.066)\end{array}$ & $\begin{array}{l}0.171^{* *} \\
(0.072)\end{array}$ & $\begin{array}{c}0.161^{\text {*** }} \\
(0.053)\end{array}$ & $\begin{array}{l}0.130^{\star *} \\
(0.059)\end{array}$ \\
\hline Board size $\mathrm{e}^{2}$ & $\begin{array}{l}-0.030^{\star \star} \\
(0.014)\end{array}$ & $\begin{array}{c}-0.032^{\star \star} \\
(0.013)\end{array}$ & $\begin{array}{c}-0.027^{\star \star} \\
(0.013)\end{array}$ & $\begin{array}{c}-0.032^{\star \star} \\
(0.013)\end{array}$ & $\begin{array}{c}-0.008^{\star \star \star} \\
(0.002)\end{array}$ & $\begin{array}{c}-0.006 * \star \\
(0.003)\end{array}$ & $\begin{array}{c}-0.005^{\star \star \star} \\
(0.002)\end{array}$ & $\begin{array}{c}-0.004^{\star \star} \\
(0.002)\end{array}$ \\
\hline $\begin{array}{l}\text { Dummy Financials } \\
\text { Dummy High Tech } \\
\text { Dummy Utilities }\end{array}$ & $\begin{array}{l}-0.849 \\
(0.768) \\
0.864 \\
(2.349) \\
1.861^{\star \star} \\
(0.787)\end{array}$ & & $\begin{array}{c}-2.245^{\star \star *} \\
(0.794) \\
-0.886 \\
(1.561) \\
1.576 \\
(1.015)\end{array}$ & & $\begin{array}{l}0.011 \\
(0.169) \\
1.573^{\star \star} \\
(0.789) \\
-0.220 \\
(0.218)\end{array}$ & & $\begin{array}{c}-0.129 \\
(0.139) \\
0.644^{\star} \\
(0.345) \\
-0.302^{\star \star} \\
(0.127)\end{array}$ & \\
\hline Constant & $\begin{array}{l}-2.361 \\
(2.807)\end{array}$ & $\begin{array}{l}-2.376 \\
(2.705)\end{array}$ & $\begin{array}{l}-2.052 \\
(2.918)\end{array}$ & $\begin{array}{l}-2.315 \\
(2.915)\end{array}$ & $\begin{array}{c}0.504 \\
(0.513)\end{array}$ & $\begin{array}{c}0.722 \\
(0.571)\end{array}$ & $\begin{array}{c}-1.100^{\star \star *} \\
(0.395)\end{array}$ & $\begin{array}{c}-0.977^{\star \star} \\
(0.416)\end{array}$ \\
\hline $\begin{array}{l}\text { Year dummies } \\
\text { Nr.Obs. } \\
\text { R-sq. } \\
\text { F } \\
\text { [p-value] }\end{array}$ & $\begin{array}{c}\text { Yes } \\
465 \\
0.047 \\
3.13 \\
{[0.000]}\end{array}$ & $\begin{array}{c}\text { Yes } \\
465 \\
0.041 \\
2.79 \\
{[0.002]}\end{array}$ & $\begin{array}{c}\text { Yes } \\
457 \\
0.073 \\
4.79 \\
{[0.000]}\end{array}$ & $\begin{array}{c}\text { Yes } \\
457 \\
0.057 \\
3.29 \\
{[0.000]}\end{array}$ & $\begin{array}{c}\text { Yes } \\
470 \\
0.077 \\
4.88 \\
{[0.000]}\end{array}$ & $\begin{array}{c}\text { Yes } \\
470 \\
0.036 \\
4.97 \\
{[0.000]}\end{array}$ & $\begin{array}{c}\text { Yes } \\
628 \\
0.081 \\
3.25 \\
{[0.000]} \\
\end{array}$ & $\begin{array}{c}\text { Yes } \\
628 \\
0.063 \\
3.42 \\
{[0.000]} \\
\end{array}$ \\
\hline
\end{tabular}

${ }^{*}$ ) All independent variables lagged one period.

Robust standard errors in parenthesis.

Last column models: all year dummies positive and statistically significant at the $1 \%$ level. 
Variables definition and descriptive statistics

\begin{tabular}{|c|c|c|c|c|c|c|}
\hline Variable & Data source & Definition & Mean & Standard deviation & Min & Max \\
\hline \multicolumn{7}{|l|}{ Ownership structure } \\
\hline Ownership share of all relevant shareholders (\%) & Consob & Total ownership share of all shareholders owning at least $2 \%$ of the firm's equity & 61,86 & 16,82 & 0 & 100 \\
\hline Top 3 relevant shareholders ownership share (\%) & Consob & Total ownership share of the three largest shareholders & 56,95 & 18,13 & 0 & 100 \\
\hline Number of relevant shareholders & Consob & Number of shareholders owning at least $2 \%$ of the firm's equity & 4 & 2,51 & 0 & 14 \\
\hline Family ownership (dummy) & Consob & Dummy equal to 1 if the firm is controlled by a family & 0,36 & 0,48 & 0 & 1 \\
\hline Shareholders agreements (dummy) & Consob & Dummy equal to 1 if there is a shareholders' agreement & 0,22 & 0,41 & 0 & 1 \\
\hline \multicolumn{7}{|l|}{ Board structure } \\
\hline Board size & Reports on corporate governance & Number of board members & 10,5 & 3,96 & 3 & 25 \\
\hline Executive members (\%) & Reports on corporate governance & Percentage of executive members in the board & 30,69 & 18,51 & 0 & 100 \\
\hline Independent members (\%) & Reports on corporate governance & Percentage of non-executive independent members in the board & 39,48 & 20,3 & 0 & 100 \\
\hline Non-executive non-independent members (\%) & Reports on corporate governance & Percentage of non-executive non-independent members in the board & 29,27 & 21,87 & 0 & 86,67 \\
\hline Minority representatives (\%) & Reports on corporate governance & Percentage of minority members in the board & 4,23 & 10 & 0 & 52,9 \\
\hline Female members (\%) & Reports on corporate governance & Percentage of female members in the board & 5,47 & 7,84 & 0 & 40 \\
\hline Executive committee (dummy) & Reports on corporate governance & Dummy equal to 1 if there is an executive committee & 0,21 & 0,41 & 0 & 1 \\
\hline Size of the executive committee & Reports on corporate governance & Number of members in the executive committee & 1,18 & 2,42 & 0 & 10 \\
\hline Compensation committee (dummy) & Reports on corporate governance & Dummy equal to 1 if there is a compensation committee & 0,78 & 0,42 & 0 & 1 \\
\hline Size of the compensation committee & Reports on corporate governance & Number of members in the compensation committee & 2,5 & 1,5 & 0 & 8 \\
\hline Audit committee (dummy) & Reports on corporate governance & Dummy equal to 1 if there is an audit committee & 0,86 & 0,35 & 0 & 1 \\
\hline Size of the audit committee & Reports on corporate governance & Number of members in the audit committee & 2,7 & 1,29 & 0 & 7 \\
\hline Minority list & Reports on corporate governance & Dummy equal to 1 if there is a minority list & 0,45 & 0,5 & 0 & 1 \\
\hline \multicolumn{7}{|l|}{ Firms' characteristics } \\
\hline Assets (thousands of Euro) & Datastream (WC02999) & sum of all assets & $1,55 \mathrm{E}+07$ & $7,53 E+07$ & 14468 & $1,01 E+09$ \\
\hline Sales (thousands of Euro) & Datastream DWSL & sum of all sales & 3300401 & $1,04 \mathrm{E}+07$ & 3311 & $8,43 \mathrm{E}+07$ \\
\hline Market value (thousands of Euro) & Datastream MV & Year-end stock price times number of shares & 2471839 & 9252211 & 5860 & $1,02 \mathrm{E}+08$ \\
\hline Free cash flow (thousands of Euro) & Datastream (DWFC) & Operating cash flows less fixed capital investments & 568328,6 & 2427911 & -7272183 & $2,30 \mathrm{E}+07$ \\
\hline Market to book & Datastream (MTBV) & Market value over book value of equity capital & 2,17 & 2,1 & $-3,52$ & 40,7 \\
\hline \multicolumn{7}{|l|}{ Firms' performance } \\
\hline & Datastream WC08326 & Net revenue over total assets & 3 & 7 & $-37,27$ & 76,28 \\
\hline Ebit & Datastream DEWB & Earnings before taxes and interests & 519364,1 & 2192813 & -739690 & $2,47 \mathrm{E}+07$ \\
\hline SD of share price & Datastream & Standard deviation of stock prices & 0,85 & 1,48 & 0,003 & 21,08 \\
\hline
\end{tabular}

